\title{
Production and water-use efficiency of Megathyrsus maximus cv. Mombaça "Guinea grass" under nitrogen and boron doses
}

\section{Produção e eficiência do uso da água de Megathyrsus maximus cv. Mombaça "Guinea grass" sob doses de nitrogênio e boro}

\begin{abstract}
Fernanda Lamede Ferreira de Jesus ${ }^{1}$; Arthur Carniato Sanches ${ }^{2 *}$; Fernando Campos Mendonça3; Adriano Bicioni Pacheco4; Débora Pantojo de Souza5; Jhon Lennon Bezerra da Silva ${ }^{6}$
\end{abstract}

\section{Highlights}

Nitrogen doses associated with irrigation reduces the seasonality of Guinea grass.

Boron fertilization showed no influence on Guinea grass production.

Guinea grass water-use efficiency can be higher than $3 \mathrm{~kg} \mathrm{~m}^{-3}$.

\begin{abstract}
Brazilian cattle production is mainly conducted with the use of cultivated or native forages, which is considered one of the most efficient ways of production. In this sense, this study aimed to evaluate the production and water-use efficiency of Guinea grass under different associations between nitrogen and boron doses, as well as different regrowth cycles. The experiment field ( $22^{\circ} 42^{\prime} 14.6^{\prime \prime} \mathrm{S}, 47^{\circ} 37^{\prime} 24.1^{\prime \prime} \mathrm{W}$, and 569-m altitude) has a regional climate classified as Cwa, which stands for a humid subtropical climate. The experimental design was randomized blocks, with a $4 \times 4 \times 11$ factorial arrangement consisting of boron $(0$, 0.181 , and $\left.0.363 \mathrm{~kg} \mathrm{ha}^{-1} \mathrm{cycle}^{-1}\right)$ and nitrogen $\left(22.7,45.5,68.2\right.$, and $\left.90.9 \mathrm{~kg} \mathrm{ha}^{-1} \mathrm{cycle}^{-1}\right)$ fertilizations, plus 11 regrowth cycles and 4 replications. The pasture of Mombaça "Guinea grass" (Megathyrsus Maximus Syn. Panicum Maximum) was irrigated by a sprinkler system. Unlike boron, nitrogen positively influenced forage production. The cycles had a strong influence on production, with winter cycles being the least productive compared to the others.
\end{abstract}

Key words: Irrigation. Water-use efficiency. Pasture. Tensiometry. Fertilization.

1 Profa, Universidade Federal Rural da Amazônia, UFRA, Tomé Açu, PA, Brazil. E-mail: fernanda.lamede@ufra.br

2 Prof., Universidade Federal de Grande Dourados, UFGD, Dourados, MS, Brazil. E-mail: arthursanches@ufgd.edu.br

3 Prof., Universidade de São Paulo/ESALQ, Piracicaba, SP, Brazil. E-mail: fernando.mendonca@usp.br

4 Top Level Technician, UFRA, Tomé Açu, PA, Brazil. E-mail: ad.pacheco@hotmail.com

${ }^{5}$ Graduate PhD Student, Universidade de São Paulo, ESALQ, Piracicaba, SP, Brazil. E-mail: dpdsouza@usp.br

${ }_{6}$ Dr. Degree, Universidade Federal Rural de Pernambuco, UFRPE, Recife, PE, Brazil. E-mail: jhonlennoigt@hotmail.com

* Author for correspondence

Received: Nov. 09, 2020 - Approved: Mar. 09, 2021 


\section{Resumo}

A produção bovina brasileira é feita principalmente com o uso de forragens cultivadas ou nativas, que é considerada umas das maneiras mais eficiente de produção. Nesse sentindo, teve-se por objetivo avaliar a produtividade e produtividade da água do capim Mombaça com diferentes combinações de nitrogênio e boro em diferentes ciclos de rebrota. O campo experimental $\left(22^{\circ} 42^{\prime} 14,6^{\prime \prime} \mathrm{S}\right.$ e $47^{\circ} 37^{\prime} 24,1^{\prime \prime} \mathrm{O}$, com altitude de $569 \mathrm{~m}$ ) possui um clima regional classificado como tipo Cwa - Subtropical ou tropical de altitude. O delineamento experimental utilizado foi um fatorial $4 \times 4 \times 11$, sendo 2 formas de adubação: boratada foram

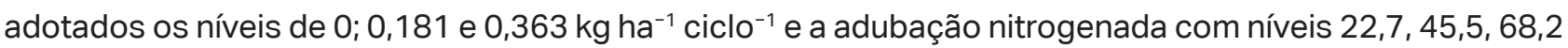
e 90,9 $\mathrm{kg} \mathrm{ha}^{-1}$ ciclo-1 $^{-1} \mathrm{com} 11$ ciclos de rebrota, e 4 repetições. A pastagem utilizada foi o capim Mombaça "Guinea grass" (Megathyrsus Maximus syn. Panicum Maximum) em sistema irrigado por aspersão. Durante o período avaliado observou-se que o nitrogênio influenciou positivamente a produção forrageira, enquanto o boro não influenciou a produção forrageira. Os ciclos tiveram forte influência na produção, sendo que os ciclos de inverno foram os menos produtivos comparados aos demais.

Palavras-chave: Irrigação. Eficiência no uso da água. Pastagem. Tensiometria. Adubação.

Brazil has extensive pasture areas and is one of the world's largest commercial cattle producers (S. C. D. Silva et al., 2009). Brazilian cattle production is based mainly on grazing systems, especially grass pastures, as it is a less expensive way of producing animal protein for human consumption (J. C. Fernandes, Buzetti, Dupas, Teixeira, \& Andreotti, 2015).

The low cost of beef production on pasture is due to climate factors that favor forage production in different regions and periods of the year. One of the advantages of livestock production on pasture is the ability of ruminants to transform fibrous foods of relatively low nutritional value into products for human consumption (Lima et al., 2018), thus the importance of pastures to produce meat and milk. However, in general, forage plants are not fertilized, losing their development potential over the years, and reducing quality and productivity (Benett, Buzetti, Silva, Bergamaschine, \& Fabricio, 2008). About 70\% of Brazilian pasture areas show some degree of degradation (Cherubin et al., 2016), which affects their nutritional value and negatively contributes to the efficiency of the system, harming animal performance (Lima et al., 2018).

Currently, the increase in competitiveness in the livestock market regarding the use of agricultural land and the search for the best returns on invested capital have led to the search for complementary production technologies to provide benefits that can be integrated into the productive system (Galindo et al., 2018). Thus, the use of fertilizers can significantly increase forage production, allowing greater capacity and resulting in an increase in milk and meat production per unit area.

Soil fertility can be improved by fertilizing the pasture. Nitrogen fertilization is the most significant in terms of gains in forage production (Coblentz, Akins, Cavadini, \& Jokela, 2017). Its application is essential for the maintenance of productivity and sustainability of pastures, and its deficiency is considered an important factor to trigger the 
degradation process. Moreover, soil acidity must be corrected and other macro- and micronutrients must be provided for nitrogen to maximize forage production in intensive production systems (Hajighasemi, KeshavarzAfshar, \& Chaichi, 2016).

Boron is one of the main micronutrients to be considered among the nutrients that must be balanced with nitrogen fertilization for pasture nutrition for performing important functions related to the growth of grasses, such as acting in the synthesis of nucleic acids and proteins, transport of carbohydrates, and synthesis of lignin and cellulose (Malavolta, 2006)

Another essential factor in forage production is the choice of plant material. Several species have been used in Brazil for pasture, such as Guinea grass, which is widely used in cattle production. The grass species Panicum maximum (Syn. Megathyrsus maximus) has one of the greatest known potentials for dry matter (DM) production in subtropical and tropical regions. The use of Megathyrsus maximus has been increasing as an option for forage due to its high leaf production and nutritional value, factors that may allow the achievement of superior animal performance (F. D. Fernandes et al., 2014).

Specific pasture management can increase forage use efficiency, resulting in better canopy structure and nutritional value (Anjos et al., 2016). Thus, pasture management strategies, such as nitrogen and boron fertilization, are very important because they can help provide the animal with a forage canopy structure with higher quality and quantity.

The study of forage plants is of fundamental importance because much of the meat and milk produced comes from herds raised on pasture. Therefore, this study aimed to evaluate the dry matter production of irrigated Guinea grass Megathyrsus Maximus (Syn. Panicum maximum cv. Mombaça) and water-use efficiency according to different nitrogen and boron fertilization in the eastern region of São Paulo State, Brazil.

\section{Material and Methods}

The experiment was carried out in the experimental area of the Department of Biosystems Engineering of the Luiz de Queiroz College of Agriculture - ESALQ/USP, in Piracicaba, SP, Brazil $\left(22^{\circ} 42^{\prime} 14.6^{\prime \prime} \mathrm{S}\right.$ and $47^{\circ} 37^{\prime} 24.1^{\prime \prime} \mathrm{W}$, with an altitude of $569 \mathrm{~m}$ ) in the period between August 11, 2017, and August 2, 2018.

The regional climate is Cwa, i.e., a humid subtropical climate, according to the Köppen classification, with hot summers and rain concentration in the summer (Pereira et al., 2016). The accumulated rainfall during the experimental period was 1,133 $\mathrm{mm}$ and water supplementation by irrigation reached 436.9 $\mathrm{mm}$. Figure 1 shows the temporal distribution of the rainfall, irrigation, average relative air humidity, and average and minimum temperatures during the experimental period. 


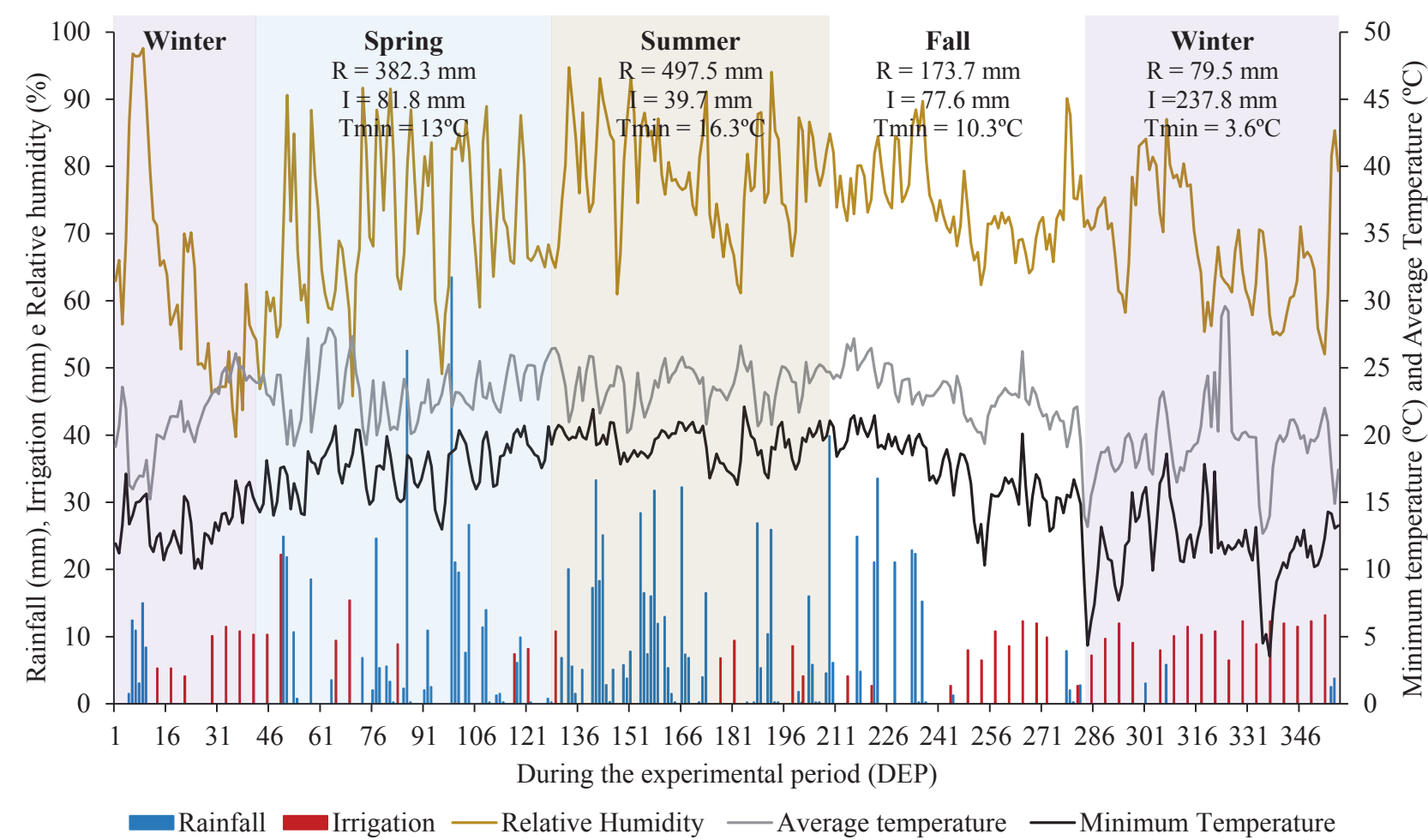

Figure 1. Rainfall $(\mathrm{R}-\mathrm{mm})$, irrigation $(\mathrm{I}-\mathrm{mm})$, average temperature $\left(\right.$ Tavg $\left.-{ }^{\circ} \mathrm{C}\right)$, minimum temperature (Tmin $-{ }^{\circ} \mathrm{C}$ ), and relative humidity (RH - \%) during the experimental period from August 11, 2017, to August 2, 2018. Piracicaba, SP, Brazil. RH: relative humidity; Tmin: minimum temperature; Tavg: average temperature.

The soil in the experimental area is classified as a clayey Oxisol (Nitossolo Vermelho Eutroférrico Latossólico, Brazilian Soil Classification System) (Weil \& Brandy, 2016). Soil acidity was corrected in the month before the experiment was set up using dolomitic limestone at a dose of 4,000 $\mathrm{kg} \mathrm{ha}^{-1}$, while base fertilization was applied according to criteria established by Raij, Cantarella, Quaggio and Furlani (1997) based on the chemical analysis of macro- and micronutrients (Tables 1 and 2).

\section{Table 1}

Chemical analysis of soil macronutrients and particle size distribution in the experimental area at depths of 0-20 and 20-40 cm. Piracicaba, SP, Brazil, 2017

\begin{tabular}{|c|c|c|c|c|c|c|c|c|c|c|c|}
\hline Depth & $\mathrm{pH}$ & $P$ & K & $\mathrm{Ca}$ & $\mathrm{Mg}$ & $\mathrm{H}+\mathrm{Al}$ & $\mathrm{Al}$ & CEC & Sand & Silt & Clay \\
\hline (cm) & $\mathrm{CaCl}_{2}$ & $\mathrm{mg} \mathrm{dm}^{-3}$ & \multicolumn{5}{|c|}{ cmolc $\mathrm{dm}^{-3}$} & cmolc $\mathrm{dm}^{-3}$ & (\%) & (\%) & (\%) \\
\hline $0-20$ & 5.7 & 37 & 0.38 & 3.0 & 1.8 & 2.0 & 0.0 & 7.18 & 35.7 & 19.2 & 45.1 \\
\hline $0-40$ & 5.6 & 31 & 0.35 & 3.0 & 1.5 & 2.5 & 0.0 & 7.35 & 29.3 & 18.7 & 52.0 \\
\hline
\end{tabular}

$\mathrm{P}=$ phosphorus $; \mathrm{K}=$ potassium; $\mathrm{Ca}=$ calcium; $\mathrm{Mg}=$ magnesium; $\mathrm{H}+\mathrm{Al}=$ potential acidity $; \mathrm{Al}=$ exchangeable aluminum; $\mathrm{CEC}=$ cation exchange capacity. 
Table 2

Chemical analysis of soil micronutrients in the experimental area at depths of $0-20$ and $20-40 \mathrm{~cm}$. Piracicaba, SP, Brazil, 2017

\begin{tabular}{|c|c|c|c|c|c|c|}
\hline Depth & $\mathrm{Cu}$ & $\mathrm{Fe}$ & $\mathrm{Zn}$ & $\mathrm{Mn}$ & B & OM \\
\hline (cm) & & & $\mathrm{g} \mathrm{dm}$ & & & $\mathrm{g} \mathrm{dm}^{-3}$ \\
\hline $0-20$ & 4.2 & 19 & 3.9 & 54.0 & 0.2 & 23 \\
\hline $0-40$ & 4.5 & 27 & 4.0 & 84 & 0.32 & 18 \\
\hline
\end{tabular}

Boron fertilization (source: boric acid) consisted of levels $0,0.181$, and $0.363 \mathrm{~kg}$ ha $^{-1}$ cycle $^{-1}$, while nitrogen (source: urea) fertilization consisted of the levels 22.7, $45.5,68.2$, and $90.9 \mathrm{~kg} \mathrm{ha}^{-1} \mathrm{cycle}^{-1}$. Boron is recommended for the maintenance of pastures, but few producers adopt its use. There is also a lack of information on applied research in the field with this nutrient. Moreover, recent studies on irrigated pastures have shown satisfactory results with the use of nitrogen, with doses varying from 0 to 100 $\mathrm{kg} \mathrm{ha}^{-1}$ cycle $^{-1}$ (Magalhães et al., 2012; Gomes et al., 2015a, 2015b; Sanches, Gomes, Rickli, Friske, \& Fasolin, 2017).

The forage used in the experiment was Megathyrsus maximus cv. Mombaça "Guinea grass" grown during an experimental year between fall/winter and spring/summer seasons. The experimental design was conducted in randomized blocks with four replications in a $4 \times 3 \times 11$ factorial scheme, consisting of four nitrogen doses $(250,500$,

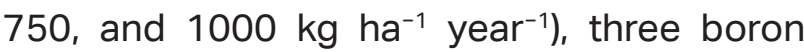
doses $\left(0,2\right.$, and $4 \mathrm{~kg} \mathrm{ha}^{-1}$ year $\left.^{-1}\right)$, and 11 regrowth/cut cycles.
Irrigation was performed with a conventional fixed and automated sprinkler system, with an $11 \times 8 \mathrm{~m}$ spacing (emitters $x$ rows). The irrigation time was variable, that is, a variable water depth and fixed irrigation frequency, according to the crop water consumption, which was measured using tensiometers.

The application intensity of sprinklers (la) was $17.1 \mathrm{~mm} \mathrm{~h}^{-1}$, working at a pressure of $30 \mathrm{mWC}$. The irrigation was composed of low-flow sprinklers, with $60 \%$ of the water availability factor $\left(\Theta_{60}=\right.$ moisture at $\left.60 \%\right)$. Moisture at field capacity $(\theta \mathrm{fc})$ was considered as the moisture corresponding to the value of the matric potential, with $\Psi_{\mathrm{m}}=0.1$ bar (Benevenute, Passo, Melo, Silva, \& Oliveira, 2016).

The current moisture values ( $(\Theta a)$ were estimated using the soil water retention curve, obtained using a tension table and Richards' extractor at the Laboratory of Soil and Water Quality of ESALQ/USP and adjusted by the Genuchten equation (van Genuchten, 1980):

$$
\theta_{a}=0.2938+\left[\frac{(0.4934-0.2938)}{\left[1+\left(0.113 \Psi_{m a}\right)^{1.3211}\right]^{0.2431}}\right] ;\left(\mathrm{R}^{2}=1.00 \text { and } \mathrm{P}<1.00\right)
$$


where $\theta_{a}$ is the current volumetric moisture $\left(\mathrm{cm}^{3} \mathrm{~cm}^{-3}\right)$ and $\Psi_{\text {ma }}$ is the current soil water matric potential (bar).

The cutting/collection cycles (CCC) were fixed according to the season, 40 days after cutting (DAC) for the fall/winter (three in the fall and two in the winter) and 28 DAC for the spring/summer (three in the spring and three in the summer), totaling 11 cycles. The residue height (post-cut) was $30 \mathrm{~cm}$, according to Simonetti, Marques and Costa (2016).

Guinea grass was subjected to botanical separation (leaf, stem, and dead material) and dried in a forced-air circulation oven $\left(65^{\circ} \mathrm{C}\right.$ for $72 \mathrm{~h}$ ) to determine the forage dry matter: total forage productivity (TFP), leaf production (LP), stem production (SP), and dead material production (DMP).

Water consumption and water-use efficiency (WUE) of forages were estimated from the total precipitated and irrigated during the experimental period in each cycle, considering the efficient water use. WUE was calculated using the following equation:

$$
\mathrm{WUE}=\frac{\mathrm{TFP}}{10 *(\mathrm{R}+\mathrm{I})}
$$

where WUE is the water-use efficiency $\left(\mathrm{kg} \mathrm{m}^{-3}\right)$, TFP is the total forage productivity $\left(\mathrm{kg} \mathrm{ha}^{-1}\right.$ $\mathrm{DM})$, and $\mathrm{R}+\mathrm{l}$ is the rainfall plus irrigation $(\mathrm{mm})$.

The experimental data were subjected to analysis of variance ( $p \leq 0.05)$ and, when significant, the means were compared by the Tukey test ( $p \leq 0.05)$ using the statistical tool SISVAR version 5.6 (D. F. Ferreira, 2019).

\section{Results and Discussion}

The results showed that Guinea grass responded linearly to nitrogen doses $\left[\left(P R O D=8.623 * \mathrm{~N}+28.463 ; \mathrm{R}^{2}=0.98\right) \mathrm{PROD}=\right.$ production in $\mathrm{Mg} \mathrm{ha}^{-1}, \mathrm{~N}=$ nitrogen doses], and the highest average production values of $6,5.8$, and $5.6 \mathrm{Mg} \mathrm{ha}^{-1}$ were found for the treatments N4B1, N4B2, and N4B0, respectively (Table 3). The highest dry matter accumulations were obtained at the highest $\mathrm{N}$ dose $(1000 \mathrm{~kg} \mathrm{~N}$ $\left.\mathrm{ha}^{-1}\right)$. Fertilization, especially with nitrogen, is essential for increasing biomass production (Silva, Costa, Faquin, Oliveira e Bernardes, 2013). Tropical forage plants are mostly highly demanding in nitrogen, which is the nutrient required in higher quantity.

The micronutrient boron (B) showed no significant results as a function of its different applications. The initial soil sample presented a value of $0.26 \mathrm{mg} \mathrm{dm}^{-3}$, which met the chemical demand of the pasture due to its small requirement for boron. Boron is involved in many physiological processes, which can be harmed by both the deficiency and the excess (toxicity). Almeida, Canto, Barth and Costa (2015) obtained no response of DM production of Guinea grass for boron doses, with a significant effect only in the production of pasture seeds.

Similarly, other studies have shown satisfactory results regarding the increase of dry matter production in response to an increase in nitrogen fertilization (Alencar et al., 2013; Munari-Escarela, Pietroski, Melo-Prado, \& Caione, 2017; Iwamoto et al., 2014; D. R. G. Silva et al., 2013; Oliveira et al., 2015). Nitrogen supply has been an important measure to increase forage production in Brazil, as soil nitrogen contents in most of the cultivated areas do not satisfactorily meet crop requirements (Rosado, Gontijo, Almeida, \& Andrade, 2014). 

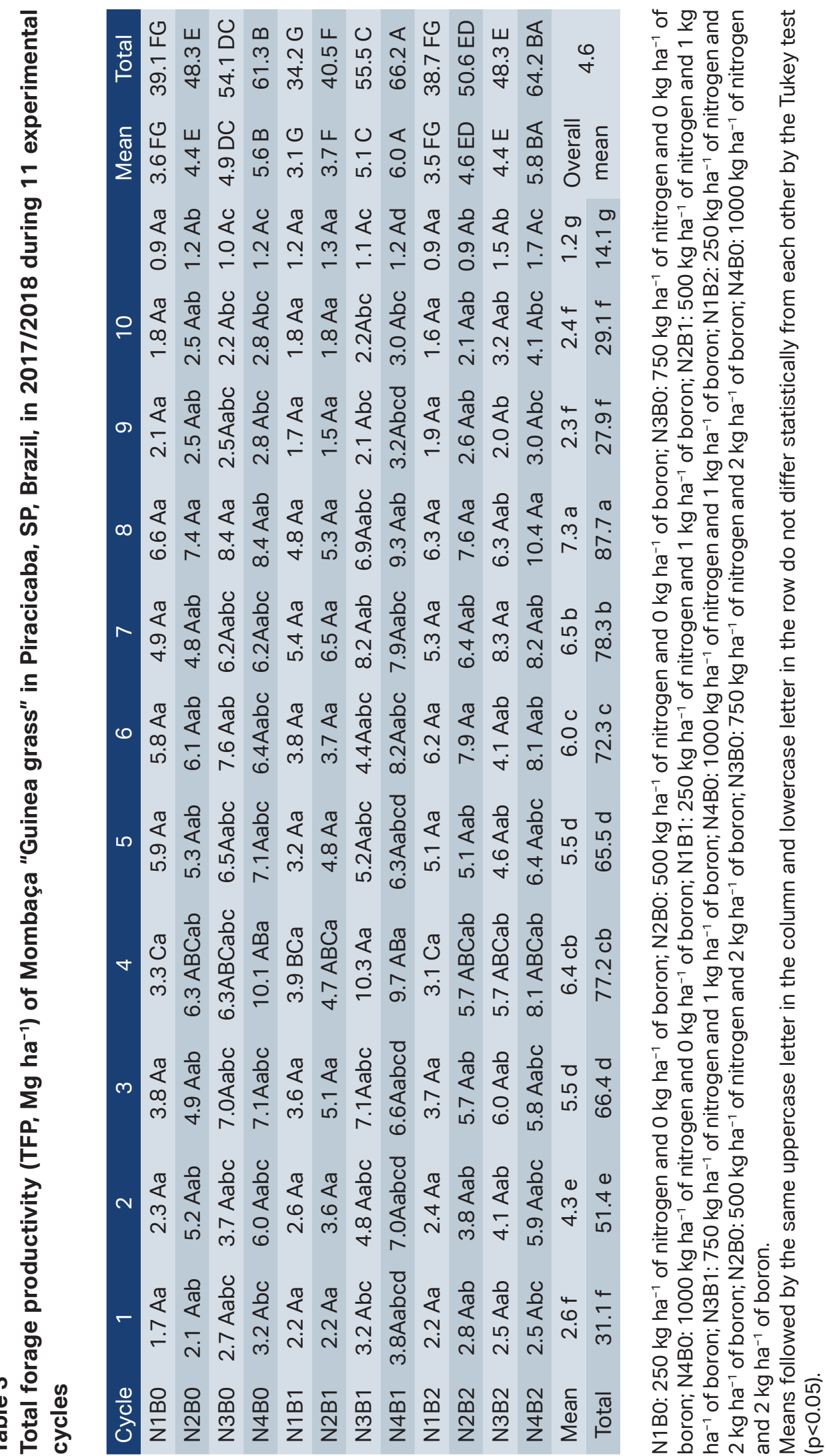
A gradual increase in production was verified from the second (beginning of spring) to the eighth cycle (beginning of fall), followed by a sharp decrease in production in the following cycles. In this case, the minimum temperature in the winter of $3.6^{\circ} \mathrm{C}$ could completely stop pasture growth (Figure 1). Some authors have already pointed out this climate condition in pastures as an integral part of the off-season and seasonality (Gomes et al., 2015b; Martins \& Silva, 2016; Reis, Santos, Oliveira, \& Santos, 2017), and even irrigation is not able to meet the need of forage plants.

All treatments followed the same trend when comparing the seasons. The highest productions were observed during the spring/ summer period, while the lowest productions were found during the fall/winter period (Figure $2 a, b$, and $c)$.

The lowest accumulated productivity in the fall/winter was $11.6 \mathrm{Mg} \mathrm{ha}^{-1}$ of dry matter, with a dose of $250 \mathrm{~kg} \mathrm{ha}^{-1}$ year $^{-1}$ of nitrogen in the presence of irrigation. The maximum productivity in the same period was $21.8 \mathrm{Mg} \mathrm{ha}^{-1}$ of DM, with a dose of $1000 \mathrm{~kg}$ $\mathrm{ha}^{-1}$ of $\mathrm{N}$. The increase in production shown in Figure 2 illustrates the importance of nitrogen fertilization associated with irrigation in increasing the production potential of Guinea grass in the dry season. Forage production seasonality is an important factor to be considered in intensive livestock. Forage production decreases up to $10 \%$ during the dry season in Brazil, considering the annual total (Alencar et al., 2010). The maintenance of pasture supply in quantity and quality throughout the year is one of the several challenges faced by Brazilian livestock. Factors such as climate conditions and soil nutrient availability for good plant development are crucial for forage production (Roma et al. 2012).
Soil fertility management and fertilization practice, together with knowledge on plant nutritional requirements and irrigation and climate effects, are factors of major importance for pasture management and can lead to higher or lower forage production (Dias, 2012).

The fluctuation in the dry matter production of forage plants throughout the year also reflects variations in the nutritional value of the forage, making it difficult to balance the supply and nutritional quality due to the seasonal production. Thus, strategies to minimize this phenomenon must be considered aiming to increase the efficiency of production systems with tropical forages. In the experiment, the use of irrigation associated with high nitrogen doses had positive effects, with an expressive dry matter accumulation in the fall/winter of around 18 to $20 \mathrm{Mg} \mathrm{ha}^{-1}$, which is usually the forage production for a whole year in extensive systems and degraded pastures or pastures in stages of degradation (Bendito, Souza, Pereira, \& Gonçalves, 2017).

Forage production reached values below $8 \mathrm{Mg} \mathrm{ha}^{-1}$ only in the fall/winter season (Figure 2d). Besides, production remained below $8 \mathrm{Mg} \mathrm{ha}^{-1}$ for all winter treatments. The spring/summer had values above $20 \mathrm{Mg}$ ha-1 in some treatments, which shows the accentuated seasonal behavior in fall/winter. Sharp decreases in the treatment with doses

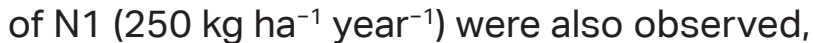
demonstrating the high performance of nitrogen in pasture fertilization.

The experiment conducted by Sanches, Souza, Jesus, Mendonça and Gomes (2019) in the same site during the experimental period, which evaluated the crop evapotranspiration (ETc) for Guinea grass and the reference evapotranspiration (ETo), was 

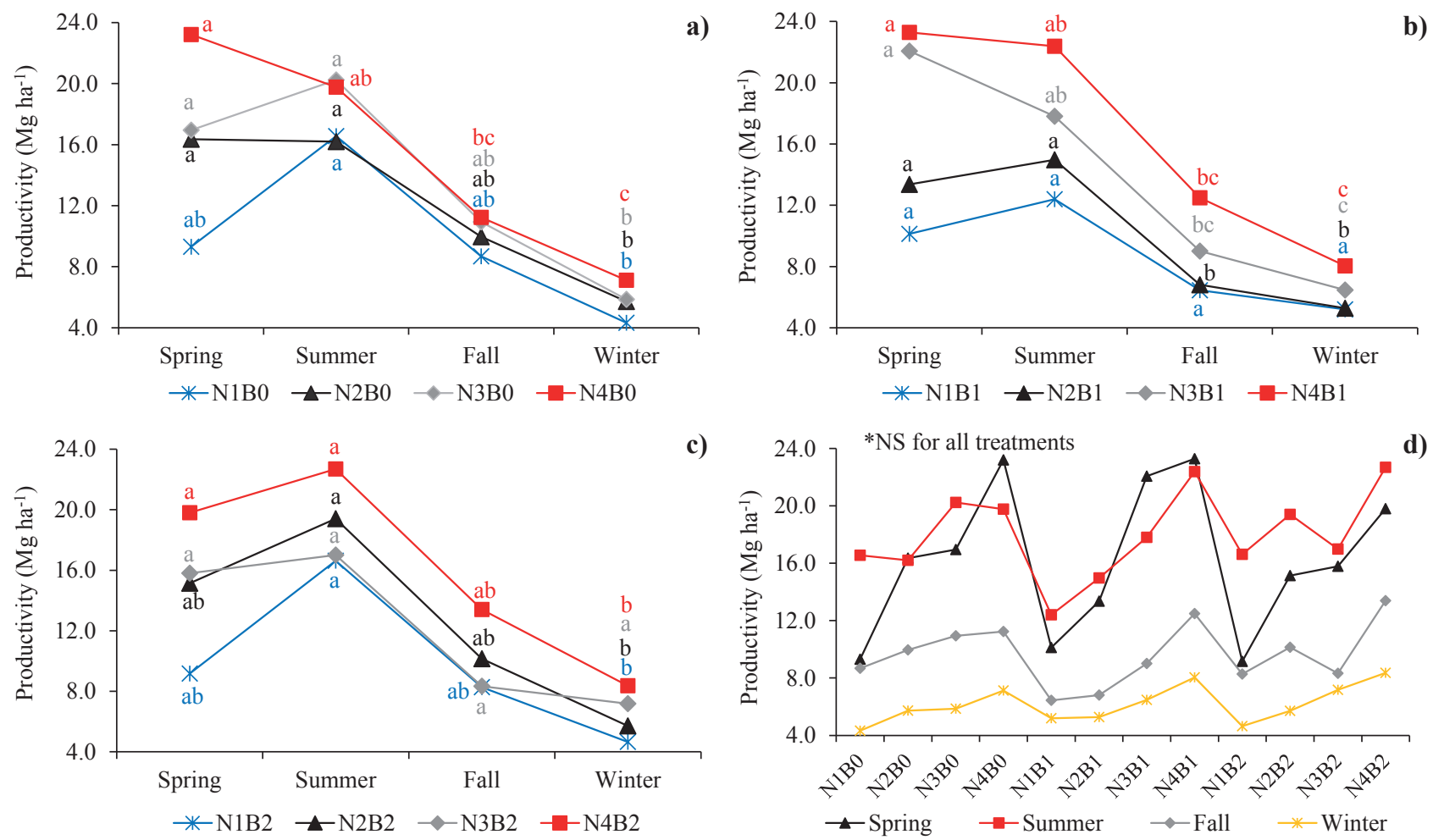

Figure 2. Mombaça "Guinea grass" productivity $\left(\mathrm{Mg} \mathrm{ha}^{-1}\right)$ per season in Piracicaba, SP, Brazil (2017/2018).

a) Productivity for four nitrogen doses at a boron dose of $0 \mathrm{~kg} \mathrm{ha}^{-1}$, b) productivity for four nitrogen doses at a boron dose of $1 \mathrm{~kg} \mathrm{ha}^{-1}$, c) productivity for four nitrogen doses at a boron dose of $2 \mathrm{~kg}$ $\mathrm{ha}^{-1}$, and d) general productivity of treatments in the four seasons. N1B0: $250 \mathrm{~kg} \mathrm{ha}^{-1} \mathrm{of}_{\text {nitrogen }}$ and $0 \mathrm{~kg} \mathrm{ha}^{-1}$ of boron; N2B0: $500 \mathrm{~kg} \mathrm{ha}^{-1}$ of nitrogen and $0 \mathrm{~kg} \mathrm{ha}^{-1}$ of boron; N3B0: $750 \mathrm{~kg} \mathrm{ha}^{-1}$ of nitrogen and $0 \mathrm{~kg} \mathrm{ha}^{-1}$ of boron; N4B0: $1000 \mathrm{~kg} \mathrm{ha}^{-1}$ of nitrogen and $0 \mathrm{~kg} \mathrm{ha}^{-1}$ of boron; N1B1: 250 $\mathrm{kg} \mathrm{ha}^{-1}$ of nitrogen and $1 \mathrm{~kg} \mathrm{ha-1}$ of boron; N2B1: $500 \mathrm{~kg} \mathrm{ha}^{-1}$ of nitrogen and $1 \mathrm{~kg} \mathrm{ha}^{-1}$ of boron; N3B1: $750 \mathrm{~kg} \mathrm{ha}^{-1}$ of nitrogen and $1 \mathrm{~kg} \mathrm{ha}^{-1}$ of boron; N4B0: $1000 \mathrm{~kg} \mathrm{ha}^{-1}$ of nitrogen and $1 \mathrm{~kg} \mathrm{ha}^{-1}$ of boron; N1B2: $250 \mathrm{~kg} \mathrm{ha}^{-1}$ of nitrogen and $2 \mathrm{~kg} \mathrm{ha}^{-1}$ of boron; N2B0: $500 \mathrm{~kg} \mathrm{ha}^{-1}$ of nitrogen and $2 \mathrm{~kg} \mathrm{ha}^{-1}$ of boron; N3B0: $750 \mathrm{~kg} \mathrm{ha}^{-1}$ of nitrogen and $2 \mathrm{~kg} \mathrm{ha}^{-1}$ of boron; N4B0: $1000 \mathrm{~kg} \mathrm{ha}^{-1}$ of nitrogen and $2 \mathrm{~kg} \mathrm{ha}^{-1}$ of boron.

used as a comparison for the volume of water supply in the Guinea grass (rain and irrigation) of the present study. The results showed a water deficit applied in the winter relative to
ETo and ETc (Table 4). Higher values were found in the fall, spring, and summer seasons, which led to accumulated rainfall of $1569.9 \mathrm{~mm}$. 
Table 4

Rainfall, irrigation, and evapotranspiration during the experimental period in Piracicaba, SP, Brazil, 2017/2018

\begin{tabular}{|c|c|c|c|c|c|c|}
\hline & \multicolumn{6}{|c|}{ Accumulated volume in the period (mm) } \\
\hline & Rainfall & Irrigation & $P+1$ & $\mathrm{ETO}_{\mathrm{FAO} 56}$ & $\mathrm{ETC}_{\text {Seasons }^{*}}$ & $\mathrm{ETC}_{\text {average*}}$ \\
\hline Winter & 79.5 & 237.8 & 317.3 & 353.7 & 389.1 & 378.5 \\
\hline Spring & 382.3 & 81.8 & 464.1 & 365.2 & 347.0 & 390.8 \\
\hline Summer & 497.5 & 39.7 & 537.2 & 330.7 & 370.3 & 353.8 \\
\hline Fall & 173.7 & 77.6 & 251.3 & 240.6 & 259.9 & 257.5 \\
\hline \multirow[t]{3}{*}{ Total } & 1133.0 & 436.9 & 1569.9 & 1290.2 & 1336.3 & 1380.6 \\
\hline & \multicolumn{6}{|c|}{ Average daily volume (mm) } \\
\hline & Rainfall & Irrigation & $P+1$ & $\mathrm{ETO}_{\mathrm{FAO} 56}$ & $\mathrm{ETC}_{\text {Seasons* }}$ & $\mathrm{ETC}_{\text {average* }}$ \\
\hline Winter & 0.7 & 1.9 & 2.6 & 2.9 & 3.2 & 3.1 \\
\hline Spring & 4.6 & 1.0 & 5.6 & 4.3 & 4.1 & 4.7 \\
\hline Summer & 5.9 & 0.5 & 6.4 & 3.9 & 4.4 & 4.2 \\
\hline Fall & 2.6 & 1.2 & 3.8 & 3.6 & 3.9 & 3.8 \\
\hline Overall mean & 3.4 & 1.1 & 4.6 & 3.6 & 3.8 & 3.9 \\
\hline
\end{tabular}

*Estimated from Sanches et al. (2019).

The value of water applied in the fall (irrigation + rainfall) was very similar to the estimated potential consumption (ETC) of Guinea grass found by Sanches et al. (2019). It shows that the evapotranspiration methods can correlate better in periods of a mild climate and little rainfall, especially when using lysimetry, in which sensors can suffer a lot from weather conditions (e.g., storms, winds, and thunderstorms).

The botanical data showed no significant changes as a function of the different doses for the stem, leaf, and dead material production (Table 5). However, the proportion of leaves in the forage was low in the winter/ fall, making it more tender and fibrous during this period. Moreover, the amount of dead material is significantly higher in the winter period.
Nitrogen had no positive effect on the percentage of leaves despite its effect on increased production. Nitrogen plays an important role in the development of tillers and, consequently, in dry matter production, as it is part of proteins and nucleic acids, which actively participate in the synthesis of organic compounds that form the plant structure (Malavolta, 2006).

Overall, the proportion of dead material in the spring and summer period was lower than in the fall and winter seasons. According to Moreira et al. (2009), tissue renewal in the rainy season is high, increasing both the growth and mortality of tillers. However, the dead material has a trend to be accumulated at the end of the rainy season since the ability to renew leaves and tillers is limited not only by the environmental condition (e.g., rainfall) but also by the radiation. 
Table 5

Average data per cycle of total forage productivity (TFP), leaf production (LP), stem production (SP), dead material production (DMP), and water-use efficiency (WUE) in Mombaça "Guinea grass". Piracicaba, SP, Brazil, 2017/18

\begin{tabular}{|cccccc|}
\hline Season & TFP $\left(\mathrm{kg} \mathrm{ha}^{-1}\right)$ & LP (\%) & SP (\%) & DMP (\%) & WUE $\left(\mathrm{kg} \mathrm{m}^{-3}\right)$ \\
\hline Winter & $6,159 \mathrm{C}$ & $67.8 \mathrm{C}$ & $23.4 \mathrm{~A}$ & $8.8 \mathrm{~B}$ & $1.94 \mathrm{~B}$ \\
\hline Spring & $16,214.2 \mathrm{AB}$ & $89.9 \mathrm{~B}$ & $8.2 \mathrm{~B}$ & $1.9 \mathrm{~A}$ & $3.49 \mathrm{~A}$ \\
\hline Summer & $18,004.3 \mathrm{~A}$ & $91.5 \mathrm{AB}$ & $7.4 \mathrm{~B}$ & $1.0 \mathrm{~A}$ & $3.35 \mathrm{~A}$ \\
\hline Fall & $9,642.8 \mathrm{BC}$ & $60.8 \mathrm{CB}$ & $34.5 \mathrm{~A}$ & $4.6 \mathrm{~A}$ & $3.84 \mathrm{~A}$ \\
\hline Treatment & TFP $\left(\mathrm{kg} \mathrm{ha}^{-1}\right)$ & LP (\%) & SP (\%) & DMP $(\%)$ & WUE $\left(\mathrm{kg} \mathrm{m}^{-3}\right)$ \\
\hline N1B0 & $38,873.31 \mathrm{FG}$ & $77.1 \mathrm{~A}$ & $19.8 \mathrm{~A}$ & $3.1 \mathrm{~A}$ & $2.48 \mathrm{~A}$ \\
\hline N2B0 & $48,233.0 \mathrm{E}$ & $80.4 \mathrm{~A}$ & $15.8 \mathrm{~A}$ & $3.8 \mathrm{~A}$ & $3.07 \mathrm{~A}$ \\
\hline N3B0 & $53,988.2 \mathrm{CD}$ & $78.3 \mathrm{~A}$ & $17.5 \mathrm{~A}$ & $4.2 \mathrm{~A}$ & $3.44 \mathrm{~A}$ \\
\hline N4B0 & $61,335.3 \mathrm{~B}$ & $77.6 \mathrm{~A}$ & $17.9 \mathrm{~A}$ & $4.5 \mathrm{~A}$ & $3.91 \mathrm{~A}$ \\
\hline N1B1 & $34,170.3 \mathrm{G}$ & $78.9 \mathrm{~A}$ & $15.8 \mathrm{~A}$ & $5.3 \mathrm{~A}$ & $2.18 \mathrm{~A}$ \\
\hline N2B1 & $40,414.8 \mathrm{~F}$ & $81.4 \mathrm{~A}$ & $15.7 \mathrm{~A}$ & $2.9 \mathrm{~A}$ & $2.57 \mathrm{~A}$ \\
\hline N3B1 & $55,357.1 \mathrm{C}$ & $78.1 \mathrm{~A}$ & $17.5 \mathrm{~A}$ & $4.4 \mathrm{~A}$ & $3.53 \mathrm{~A}$ \\
\hline N4B1 & $66,203.6 \mathrm{~A}$ & $82.8 \mathrm{~A}$ & $14.1 \mathrm{~A}$ & $3.1 \mathrm{~A}$ & $4.22 \mathrm{~A}$ \\
\hline N1B2 & $38,707.7 \mathrm{FG}$ & $72.9 \mathrm{~A}$ & $19.5 \mathrm{~A}$ & $7.6 \mathrm{~A}$ & $2.47 \mathrm{~A}$ \\
\hline N2B2 & $50,415.1 \mathrm{DE}$ & $79.5 \mathrm{~A}$ & $16.3 \mathrm{~A}$ & $4.3 \mathrm{~A}$ & $3.21 \mathrm{~A}$ \\
\hline N3B2 & $48,295.0 \mathrm{E}$ & $79.5 \mathrm{~A}$ & $17.9 \mathrm{~A}$ & $2.6 \mathrm{~A}$ & $3.08 \mathrm{~A}$ \\
\hline N4B2 & $64,249.9 \mathrm{AB}$ & $82.1 \mathrm{~A}$ & $15.1 \mathrm{~A}$ & $2.8 \mathrm{~A}$ & $4.09 \mathrm{~A}$ \\
\hline
\end{tabular}

Means followed by the same uppercase letter in the column do not differ statistically from each other by the Tukey test $(p<0.05)$.

\section{Conclusion}

Nitrogen positively influenced the productivity of Guinea grass, with the highest production of approximately $60 \mathrm{Mg} \mathrm{ha}^{-1}$ at the highest dose of $1000 \mathrm{~kg}$ of $\mathrm{N} \mathrm{ha}^{-1}$ year $^{-1}$.

Boronfertilization showed no significant influence on the productivity of Guinea grass and its water-use efficiency.

Guinea grass showed a strong production fluctuation over the cycles. The fall/ winter season had a negative influence on the forage supply compared to the spring/summer season.
Irrigation, despite decreasing the effects of seasonality, was not able to match the production capacity of forage in different seasons.

The lowest water-use efficiency was observed in the winter, with a value of $1.94 \mathrm{~kg}$ $\mathrm{m}^{-3}$ of available water, while the other stations reached values higher than $3 \mathrm{~kg} \mathrm{~m}^{-3}$.

\section{Acknowledgment}

The authors would like to thank the Coordination for the Improvement of Higher Education Personnel (CAPES) and the National 
Council for Scientific and Technological Development (CNPq) for granting the scholarships.

\section{References}

Alencar, C. A. B. D., Cunha, F. F. D., Martins, C. E., Cóser, A. C., Oliveira, R. A. D., \& Araújo, R. A. S. (2013). Adubação nitrogenada e estações anuais na produção de capins irrigados no leste mineiro sob corte. Revista Brasileira de Saúde e Produção Animal, 14(3), 413-425. doi: 10.1590/S15 19-99402013000300002

Alencar, C. A. B. D., Oliveira, R. A. D., Cóser, A. C., Martins, C. E., Figueiredo, J. L. A., Cunha, F. F. D.,... Leal, B. G. (2010). Produção de seis capinsmanejadosporpastejo sob efeito de diferentes doses nitrogenadas e estações anuais. Revista Brasileira de Saúde e Produção Animal, 11(1), 48-58. Retrieved from https://periodicos.ufba.br/index.php/ rbspa/article/view/40259/22423

Almeida, G. M., Canto, M. W., Barth, A. Neto \& Costa, A. C. S. (2015). Resposta da cultura de sementes de capim-mombaça a épocas e doses de adubação de boro. Semina: Ciências Agrárias, 36(3), 15451557. doi: 10.5433/1679-0359.2015v36n $3 p 1545$

Anjos, A. J., Gomide, C. A. M., Ribeiro, K. G., Madeiro, A. S., Morenz, M. J. F., \& Paciullo, D. S. C. (2016). Massa de forragem e composição morfológica de pastagem de capim-marandu em período de repouso. Ciência e Agrotecnologia, 40(1), 79-86. doi: 10.1590/S1413-70542016000100007

Bendito, B. P. C., Souza, P. A., Pereira, M. A., \& Gonçalves, D. S. (2017). Diagnóstico ambiental e proposição de uso de saf para área de pastagem degradada. Geoambiente On-Line, 29(1), 148-163. doi: 10.5216/revgeoamb.v0i29.42599

Benett, C. C. S., Buzetti, S., Silva, K. S., Bergamaschine, A. F., \& Fabricio, J. A. (2008). Produtividade e composição bromatológica do capim-marandu a fontes e doses de nitrogênio. Ciência e Agrotecnologia, 32(5), 1629-1636. doi: 10.1590/S1413-70542008000500041

Benevenute, P. A. N., Passso, L. A. C., Melo, L. B. B., Silva, É. A., \& Oliveira, G. C. (2016). Synthetic polymers on water retention and pore distribution in a clayey latosol. Revista Scientia Agraria, 17(3), 24-30. doi: 10.5380/rsa.v17i3.50268

Cherubin, S. R., Karlen, D. L., Franco, A. L. C., Tormena, C. A., Cerri, C. E. P., Davies, C. A., \& Cerri, C. C. (2016). Soil physical quality response to sugarcane expansion in Brazil. Geoderma, 267(4), 156-168, doi: 10.1016/j.geoderma.2016.01.004

Coblentz, W. K., Akins, M. S., Cavadini, J. S., \& Jokela, W. E. (2017). Net effects of nitrogen fertilization on the nutritive value and digestibility of oat forages. Journal of Dairy Science, 100(3), 1739-1750. doi: 10.3168/jds.2016-12027

Dias, M. B., Fo. (2012). Desafios da produção animal em pastagens na fronteira agrícola brasileira. (Documentos, 382). Belém, PA: EMBRAPA Amazônia Oriental. Retrieved from https://www.infoteca.cnptia.embrapa. br/bitstream/doc/925646/1/Doc382.pdf

Fernandes, F. D., Ramos, A. K. B., Jank, L., Carvalho, M. A., Martha, G. B., Jr., \& Braga, G. J. (2014). Forage yield and nutritive 
value of Panicum maximum genotypes in the Brazilian savannah. Scientia Agricola, 71(1), 23-29. doi: 10.1590/S0103-90162 014000100003

Fernandes, J. C., Buzetti, S., Dupas, E., Teixeira, M. C. M., Fo., \& Andreotti, M. (2015). Sources and rates of nitrogen fertilizer used in Mombasa guineagrass in the Brazilian Cerrado region. African Journal of Agricultural Research, 10(19), 20762082. doi: $10.5897 / A J A R 2014.9276$

Ferreira, D. F. (2019). Sisvar: a computer analysis system to fixed effects splitplot type designs. Revista Brasileira de Biometria, 37(4), 529-535. doi: 10.28951/ rbb.v37i4.450

Galindo, F. S., Beloni, T., Buzetti, S., Teixeira, M. C. M., F'., Dupas, E., \& Ludkiewicz, M. G. Z. (2018). Technical and economic viability and nutritional quality of Mombasa guinea grass silage production. Acta Scientiarum. Agronomy, 40(1), e36395. doi: 10.4025/ actasciagron.v40i1.36395

Gomes, E. P., Rickli, M. E., Cecato, U., Farhate, C. V. V., Goes, R. H. T. B., \& Oliveira, E. (2015a). Productivity of Tifton 85 grass irrigated and overseeded with winter forages. Acta Scientiarum. Animal Sciences, 37(2), 123128. doi: 10.4025/actascianimsci.v37i2. 25512

Gomes, E. P., Rickli, M. E., Cecato, U., Vieira, C. V, Sapia, J. G., \& Sanches, A. C. (2015b). Produtividade de capim Tifton 85 sob irrigação e doses de nitrogênio. Revista Brasileira de Engenharia Agrícola e Ambiental, 19(4), 317-323. doi: 10.15 90/1807-1929/agriambi.v19n4p317-323
Hajighasemi, S., Keshavarz-Afshar, R., \& Chaichi, M. R. (2016). Nitrogen Fertilizer and Seeding Rate Influence on Grain and Forage Yield of Dual Purpose Barley. Agronomy Journal, 108(4), 1486-1494. doi: 10.2134/agronj2015.0447

Iwamoto, B. S., Cecato, U., Ribeiro, O. L., Mari, G. C., Peluso, E. P., \& Lins, T. O. J. D. (2014). Produção e composição morfológica do capim-tanzânia fertilizado com nitrogênio nas estações do ano. Bioscience Journal, 30(2), 530-538. Recuperado de http://www. seer.ufu.br/index.php/biosciencejournal/ article/ view/18078

Lima, D. M., Abdalla, A. L., F., Lima, P. D. M. T., Sakita, G. Z., McManus, C., Abdalla, A. L., \& Louvandini, H. (2018). Morphological characteristics, nutritive quality, and methane production of tropical grasses in Brazil. Pesquisa Agropecuária Brasileira, 53(3), 323-331. doi: 10.1590/s0100-204x 2018000300007

Magalhães, J. A., Carneiro, M. S. S., Andrade, A. C., Pereira, E. S., Souto, J. S., Pinto, M. S. C.,... Mochel, W. J. E., Fo. (2012). Eficiência do nitrogênio, produtividade e composição do capim-andropogon sob irrigação e adubação. Archivos de Zootecnia, 61(236), 577-588. doi: 10.4321/S000405922012000400010

Malavolta, E. (2006). Manual de nutrição mineral de plantas. São Paulo, SP: Agronômica Ceres.

Martins, J. C., \& Silva, A. L. P. (2016). Estacionalidade e planejamento forrageiro. Revista Eletrônica Biociências, Biotecnologia e Saúde, 3(12), 1-3. Retrieved from https://interin.utp.br/index. php/GR1/ article/view/1776 
Moreira, L. D. M., Martuscello, J. A., Fonseca, D. M. D., Mistura, C., Morais, R. V. D., \& Ribeiro, J. I., Jr. (2009). Perfilhamento, acúmulo de forragem e composição bromatológica do capim-braquiária adubado com nitrogênio. Revista Brasileira de Zootecnia, 38(9), 1675-1684. doi: 10.1590/S1516-35 982009000900006

Munari-Escarela, C., Pietroski, M., Mello-Prado, R. D., \& Caione, G. (2017). Effect of nitrogen fertilization on productivity and quality of Mombasa forage (Megathyrsus maximum cv. Mombasa). Acta Agronomica, 66(1), 42-48. doi: 10.15446/acag.v66n1.53420

Oliveira, E. M., Oliveira, J. D. C., Fo., Oliveira, R. A., Oliveira, R. M., Cecon, P. R., \& Cóser, A. C. (2015). Efeito da aplicação de diferentes lâminas de irrigação e doses de nitrogênio e potássio na produção do capim Tanzânia. Revista Ambiente \& Água, 10(3), 698-706. doi: 10.4136/ambi-agua.1595

Pereira, F. F. S., Pai, E. D., Montenegro, R. J. V., Román, R. M. S., González, A. M. G. O., \& Escobedo, J. F. (2016). Estudo Comparativo da evapotranspiração de referência entre localidades do estado de São Paulo e na província de Habana. Irriga, 21(2), 395-408. doi: 10.15809/irriga. 2016v21n2p395-408

Raij, B. Van, Cantarella, H., Quaggio, J. A., \& Furlani, Ã. M. C. (1997). Recomendações de adubação e calagem para o estado de São Paulo (3nd ed.). Campinas, SP: Instituto Agronômico de Campinas.

Reis, M. M., Santos, L. D. T., Oliveira, F. G., \& Santos, M. V. (2017). Irrigação de pastagens tropicais: desafios e perspectivas. Unimontes Científica, 19(1), 178-190. Retrieved from http://www.ruc. unimontes.br/index.php/unicientifica/ article/view/392

Roma, C. F. D. C., Cecato, U., Soares, C. V., Fo., Santos, G. T. D., Ribeiro, O. L., \& Iwamoto, B. S. (2012). Morphogenetic and tillering dynamics in Tanzania grass fertilized and non-fertilized with nitrogen according to season. Revista Brasileira de Zootecnia, 41(3), 565-573. doi: 10.1590/S1516-35 982012000300013

Rosado, T. L., Gontijo, I., Almeida, M. S. D., \& Andrade, F. V. (2014). Fontes e doses de nitrogênio e alterações nos atributos químicos de um latossolo cultivado com capim-mombaça. Revista Brasileira de Ciência do Solo, 38(3), 840-849. doi: 10.1590/S0100-06832014000300015

Sanches, A. C., Gomes, E. P., Rickli, M. E., Friske, E., \& Fasolin, J. P. (2017). Productivity and nutritive value of Tifton 85 in summer, with and without irrigation under different nitrogen doses. Revista Engenharia Agrícola, 37(2), 246-256. doi: 10.1590/1809-4430-eng.agric.v37n2p2 $46-256 / 2017$

Sanches, A. C., Souza, D. P. D., Jesus, F. L. F. D., Mendonça, F. C., \& Gomes, E. P. (2019). Crop coefficients of tropical forage crops, single cropped and overseeded with black oat and ryegrass. Scientia Agricola, 76(6), 448-458. doi: 10.1590/1678-992x-20170386

Silva, D. R. G., Costa, K. A. P., Faquin, V., Oliveira, I. P., \& Bernardes, T. F. (2013). Doses e fontes de nitrogênio na recuperação das características estruturais e produtivas do capim-marandu. Revista Ciência Agronômica, 44(1), 184-191. doi: 10.1590/ S1806-66902013000100023 
Silva, S. C. D., Bueno, A. A. D. O., Carnevalli, R. A., Uebele, M. C., Bueno, F. O., Hodgson, J.,... Morais, J. P. G. D. (2009). Sward structural characteristics and herbage accumulation of Panicum maximum cv. Mombaça subjected to rotational stocking managements. Scientia Agricola, 66(1), 8-19. doi: 10.1590/S010390162009000100002

Simonetti, A., Marques, W. M., \& Costa, L. V. C. (2016). Produtividade de Capim-Mombaça (Panicum maximum), com diferentes doses de Biofertilizante. Brazilian Journal of Biosystems Engineering, 10(1), 107115. doi: 10.18011/bioeng2016v10n1 p107-115 van Genuchten, M. T. (1980). A closed-form equation for predicting the hydraulic conductivity of unsaturated soils. Soil Science Society of America Journal, 44(5), 892-898. doi: 10.2136/sssaj1980.03615 $995004400050002 x$

Weil, R. R., \& Brady, N. C. (2016). The Nature and properties of soils (5nd ed.). New York, NY: Pearson. 
